\title{
GENETIC-PHYTOHORMONAL INTERACTIONS IN MALE FERTILITY AND MALE STERILITY PHENOTYPE EXPRESSION IN SUNFLOWER (Helianthus annuus L.)
}

Communication 1. COMPARATIVE INVESTIGATION OF AUXIN AND GIBBERELLIN QUANTITIES IN DIVERSE SUNFLOWER GENOTYPES

\author{
Duca, M.
}

Moldova State University, Plant Biology Department, 60, A. Mateevici Street, 2009 Chisinau, Republic of Moldova

\section{SUMMARY}

Amounts of indole-3-acetic acid (IAA) and gibberellic acid $\left(\mathrm{GA}_{3}\right)$ in vegetative and reproductive tissues of diverse sunflower genotypes have been investigated using gas-liquid chromatography. Quantification of endogenous $\mathrm{GA}_{3}$ content in the homozygous line MB 514, characterized by cytoplasmic male sterility $(\mathrm{cms})$, revealed a lower level of the hormone in contrast to the fertility restorer line RW $637 \mathrm{Rf}$. The highest amount of IAA was found in the heterozygous $F_{1}$ hybrid obtained by crossing these lines, regardless of tissues and ontogenetic phases analyzed. Similar features were found in leaves, apices, inflorescences and disk flowers in most of the investigated variants.

Key words: auxins, cms-Rf system, gibberellins, Helianthus annuus L., male fertility, male sterility

\section{INTRODUCTION}

The genetic cms-Rf system (cytoplasmic male sterility-pollen fertility restoration) is a well-known and extensively studied phenomenon, due to its importance in heterosis breeding of commercial hybrid (Vranceanu and Stoenescu, 1971a, 1971b; Voscoboinik, 1977; Anascenko, 1977). Besides, this genetic system represents a useful model for study of nucleus-cytoplasm interaction mechanisms in male sterility-fertility expression. It was shown that $\mathrm{cms}$ in sunflower is associated with mitochondrial gene orfH522 (Laver et al., 1991; Horn et al., 1994) that can be suppressed in $\mathrm{F}_{1}$ hybrids based on $\mathrm{cms}$ by the action of nuclear-encoded fertility restorer genes, homozygous and heterozygous $\mathrm{R} f$ genes (Vranceanu and Stoenescu, 1971b, 1975; Anascenko and Duca, 1985a, 1985b).

* Corresponding author: Phone: 3732 577521; Fax: 3732 739280; e-mail: mduca2000@yahoo.com 
Also, male sterility can be induced by gibberellic acid $\left(\mathrm{GA}_{3}\right)$ treatment of plants (Anascenko, 1971) and the same class of phytohormones restores male fertility in sterile plants (Kasembe, 1967). These phenomena sustain the point of view that plant hormones regulate the nucleus and other cellular structures activity by inductive or suppressive cytoplasmic systems of gene expression (Collett et al., 2000). It was supposed that the phenotype expression of hereditary male fertility/sterility traits is under phytohormone regulation.

Quantification of IAA and $\mathrm{GA}_{3}$ endogenous levels in five sunflower genotypes during their ontogenesis was carried out to study effects of interactions between genetic (nuclear and mitochondrial) factors and phytohormones on $\mathrm{cms}-\mathrm{R} f$ phenotype expression and how these interactions influence the physiological and biochemical basis of microsporogenesis.

Two isonuclear lines distinguished only by cytoplasm genes (MB 514 and MB $514 \mathrm{cms}$ with mitochondrial orfH522), the line RW $637 \mathrm{Rf}$ with nuclear homozygous restoration nuclear gene $\mathrm{R} f$ and their $\mathrm{F}_{1}$ hybrid with restored male fertility (Rf) were chosen for analyses. In addition, we studied two functional states of the male gametophyte (male sterility/fertility) in the same nuclear context, using the phenocopy method, which could provide information on nuclear effects on mitochondrial genome expression related to the $\mathrm{cms}$-Rf genetic system.

\section{MATERIAL AND METHODS}

\section{Plant materials}

Sunflower plants were cultivated at the experiment field of Moldova State University applying conventional practices (Vranceanu, 1973; Vronskih, 1980) during four years. Sunflower (Helianthus annuus L.) seeds were kindly provided by SRC Magroselect (Soroca, Republic of Moldova).
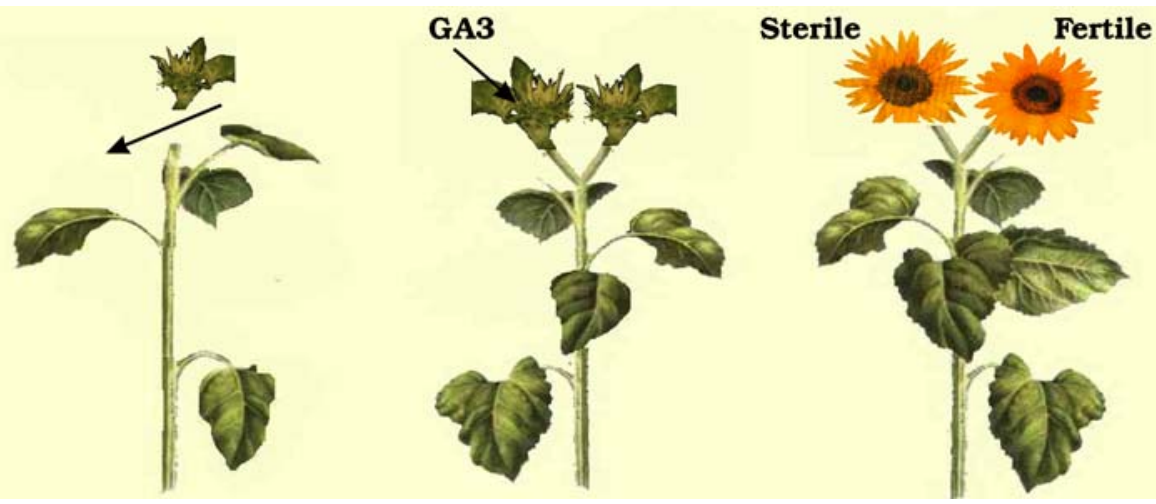

Figure 1: Schematic representation of producing phenocopies of sunflower plants

Apex decapitation at two-leaf stage is a good way to obtain phenocopies, which are known as convenient models for functional activity study of the gene. As a result of apical dominance exclusion, two lateral branches have developed. One of them was treated with exogenous gibberellic acid $(\mathrm{GA}+)$. Thus, we obtained two inflores- 
cences on the same sunflower plant, one fertile and another with induced male sterility (Figure 1).

\section{EXPERIMENTAL CONDITIONS}

Treatment with exogenous gibberellic acid. $\mathrm{GA}_{3}$ (Sigma) solution was prepared by dissolving $\mathrm{GA}_{3}$ in a small amount of ethanol (96\%), and further diluting it with distilled water to a final concentration of $0.005 \%$. Plant spraying with $\mathrm{GA}_{3}$ solution was carried out at the flower bud stage. At this stage, prior to disk flower opening, male meiosis occurs in their anthers (Anascenko, 1971). Non-GA 3 treated plants (control) were sprayed with distilled water. For assaying non-GA 3 treated plants (control) and $\mathrm{GA}_{3}$ treated plants were assayed 24 hours after the treatment.

Phytohormone extraction. Plant materials were collected at various vegetative stages that were correlated with development and microsporogenesis stages. Phytohormone assays were performed on cotyledons, apices with 2-3 true leaves, inflorescences without bracts and disk flowers without parenchyma tissues of peduncles. Heads were sliced radially, to analyze the anthers at different development stages on the single inflorescence.

Fresh plant material (about $10 \mathrm{~g}$ ) was harvested in the morning. The samples were homogenized and fixed in cold $\left(-20^{\circ} \mathrm{C}\right) 80 \%$ acetone $(1: 30$ ratio) and extracted at $3-5^{\circ} \mathrm{C}$ during $24 \mathrm{~h}$. After a series of organic extractions and purifications the extracts were dried in vacuum at $40^{\circ} \mathrm{C}$. The residue was dissolved in $0.1 \mathrm{ml}$ N,Obis(trimethylsilyl)-acetamide with addition of $0.05 \mathrm{ml}$ of trimethylchlorosilane (1\%) and then subjected to chromatography.

Chromatographic analysis. Quantitative analysis of phytohormones was performed using the gas-liquid chromatographic method and indole-3-acetic acid and gibberellic acid (Sigma) as internal standards, as described previously by Cavell et al. (1967) and modified by Duca et al. (1997).

A gas chromatograph FRACTOVAP 4200, equipped with flame ionization detector, line programs for temperature MOD 410, integrator MEGA SERIES SP 4270, and rustproof column $(2 \mathrm{~m} \times 4 \mathrm{~mm}$ ) with 5\% SE-30 DMCS Cromoton W, 60/80 mesh $(0.15-0.2 \mathrm{~mm})$, was used for analysis with $\mathrm{N}_{2}-25 \mathrm{ml} / \mathrm{min}$ as gas carrier. The air flow was maintained at $300 \mathrm{ml} / \mathrm{min}$, the hydrogen flow at $25 \mathrm{ml} / \mathrm{min}$. The injector temperature was $+210^{\circ} \mathrm{C}$, the detector temperature also $+210^{\circ} \mathrm{C}$.

Temperature regime. The phytohormones were determined using the following temperature regime: after the injection, the temperature was maintained at $60^{\circ} \mathrm{C}$ for $4 \mathrm{~min}$, and then increased to $220^{\circ} \mathrm{C}$ at the rate of $12^{\circ} \mathrm{C} / \mathrm{min}$. This temperature was maintained until the end of the chromatography run. The phytohormone content was expressed in ng per gram of fresh weight (ng/g fwt).

Data are presented as means $\pm \mathrm{SE}$ (standard errors) of three separate experiments ( $\mathrm{n}=6$ for each experiment). Student's $t$ test $(\mathrm{P}<0.05$ and $\mathrm{P}<0.09$ ) was used to determine the statistical significance of differences between the genotypes. 


\section{RESULTS AND DISSCUSION}

Plant hormones metabolism and keeping the hormonal balance in appropriate temporal and spatial patterns affect the intensity, localization, structure and quality of all morphogenetic processes. The pathways of GA biosynthesis and catabolism and their physiological role have been investigated for many years by a variety of approaches, including the application of active GAs, chemical inhibitors of GA biosynthesis, and the analysis of mutants of plants such as maize, pea, and Arabidopsis (Kende and Zeevaart, 1997).

IAA and $\mathrm{GA}_{3}$ are essential hormones that act synergetically on diverse developmental processes in plants (Ross and O'Neil, 2001). Moreover, auxins stimulate gibberellin biosynthesis (Symoons and Reid, 2002). Based on this information, quantitative analysis of hormonal balance variation has been performed on some sunflower genotypes including $\mathrm{F}_{1}$ hybrids and their parent lines, during different ontogenetic stages. Our results showed the quantitative variation of IAA and $\mathrm{GA}_{3}$ levels depended on plant tissues, development stages (Duca and Port, 2002) and environmental factors (Duca, 2003).

The most interesting data obtained relate to hormone amounts in different sunflower genotypes that compose the $\mathrm{cms}$-Rf genetic system. The $\mathrm{F}_{1}$ hybrid was found to contain the highest IAA amount versus RW $637 \mathrm{Rf}$, the male fertility restorer line, which had a lower hormone level. These features were found for apices, leaves and inflorescences (Table 1). Hormone levels in roots showed no significant quantitative variations between the studied genotypes.

Table 1: IAA amounts in different sunflower genotypes, ng/g fwt

\begin{tabular}{|c|c|c|c|c|c|c|}
\hline \multirow{3}{*}{ Genotype } & \multirow{3}{*}{$\begin{array}{c}\text { Plant } \\
\text { number: } \\
\frac{\text { fertile }}{\text { sterile }}\end{array}$} & \multirow{3}{*}{$\frac{\text { Phenotype }}{\text { Genotype }}$} & \multicolumn{4}{|c|}{ Ontogenetic phase } \\
\hline & & & \multicolumn{2}{|c|}{ First pair of true leaves } & \multicolumn{2}{|c|}{ Flower bud stage } \\
\hline & & & Roots & Apex & Leaves & Inflorescence \\
\hline $\mathrm{F}_{1}$ & $\frac{76}{0}$ & $\frac{\text { fertile }}{\mathrm{SR} f}$ & $32.79 \pm 0.12$ & $70.98 \pm 0.31$ & $62.99 \pm 0.64$ & $81.64 \pm 0.29$ \\
\hline MB $514 \mathrm{cms}$ & $\frac{2}{58}$ & $\frac{\text { sterile }}{\text { S rfrf }}$ & $30.47 \pm 0.24$ & $57.03 \pm 0.05$ & $60.15 \pm 1.17$ & $77.40 \pm 0.83$ \\
\hline RW $637 \mathrm{R} f$ & $\frac{78}{0}$ & $\frac{\text { fertile }}{\text { F RfRf }}$ & $31.71 \pm 013$ & $50.41 \pm 0.25$ & $54.99 \pm 4.70$ & $61.05 \pm 1.86$ \\
\hline \multirow{2}{*}{ LSD } & \multicolumn{2}{|c|}{0.95} & 0.093 & 0.432 & 0.265 & 0.367 \\
\hline & \multicolumn{2}{|c|}{0.99} & 0.140 & 0.654 & 0.401 & 0.556 \\
\hline
\end{tabular}

$\mathrm{S}$ - male sterile cytoplasm containing mitochondrial orfH522; F-male fertile cytoplasm

It is known that IAA induces DNA replication (Barlow, 1976). High IAA level in $\mathrm{F}_{1}$, associated with increased mitotic activity (Capatina, 2004) and with other morphological and physiological indices (Savca et al., 2002), suggests that correlation exists between IAA amount and heterosis. It is also possible that the low IAA amount in the homozygous line RW $637 \mathrm{Rf}$ is the cause of the reduced height of these plants (Savca et al., 2002). 
It is important to emphasize that the gibberellin level in all studied tissues and genotypes of sunflower was six-fold less than the IAA level, as has been shown for maize (Polevoi, 1992). Highest $\mathrm{GA}_{3}$ concentrations were found in the male fertile genotypes, the $\mathrm{F}_{1}$ hybrid and the line RW $637 \mathrm{Rf}$, which was distinguished by the increased biosynthesis during ontogenesis (Table 2). The intensity of phytohormone accumulation was significantly higher for the line RW $637 \mathrm{R} f$ than for the $\mathrm{F}_{1}$ hybrid and the line MB $514 \mathrm{cms}$ (Duca, 1998).

The gibberellin level had maximal values in roots and leaves of heterozygous plants and in the apices and inflorescences of homozygous plants, but these differences were not statistically significant either at 0.95 or 0.99 probability levels.

Table 2: Gibberellin content in different sunflower genotypes, ng/g fwt

\begin{tabular}{|c|c|c|c|c|c|c|}
\hline \multirow{3}{*}{ Genotype } & \multirow{3}{*}{$\begin{array}{c}\text { Plant } \\
\text { number } \\
\frac{\text { fertile }}{\text { sterile }}\end{array}$} & \multirow{3}{*}{$\frac{\text { Phenotype }}{\text { Genotype }}$} & \multicolumn{4}{|c|}{ Ontogenetic phase } \\
\hline & & & \multicolumn{2}{|c|}{ First pair of true leaves } & \multicolumn{2}{|c|}{ Flower bud stage } \\
\hline & & & Roots & Apex & Leaves & Inflorescence \\
\hline $\mathrm{F}_{1}$ & $\frac{76}{0}$ & $\frac{\text { fertile }}{\text { S Rf }}$ & $2.04 \pm 0.05$ & $16.94 \pm 0.03$ & $18.07 \pm 0.21$ & $14.3 \pm 0.24$ \\
\hline MB $514 \mathrm{cms}$ & $\frac{2}{58}$ & $\frac{\text { sterile }}{\text { S rfff }}$ & $0.36 \pm 0.03$ & $11.82 \pm 0.87$ & $7.21 \pm 0.63$ & $9.50 \pm 0.42$ \\
\hline RW $637 \mathrm{Rf}$ & $\frac{78}{0}$ & $\frac{\text { fertile }}{\text { F RfRf }}$ & $0.97 \pm 0.04$ & $17.40 \pm 0.20$ & $17.30 \pm 1.03$ & $17.40 \pm 0.52$ \\
\hline \multirow{2}{*}{ LSD } & \multicolumn{2}{|c|}{0.95} & 1.868 & 0.493 & 1.050 & 0.709 \\
\hline & \multicolumn{2}{|c|}{0.99} & 2.828 & 0.747 & 1.590 & 1.074 \\
\hline
\end{tabular}

$\mathrm{S}$ - male sterile cytoplasm containing mitochondrial orfH522; F-male fertile cytoplasm

Isogenic lines and phenocopies of sunflower are a good experimental genetic system for investigation of phytohormone interactions and their role in gene expression. Thus, the IAA level during the ontogenesis of the three sunflower lines, MB 514, MB $514 \mathrm{cms}$ and MB 514 treated with exogenous $\mathrm{GA}_{3}$, showed a lower value in the male sterile homozygous line than in its male fertile analogue, characterized by normal bisexual flowers with fertile pollen (Table 3 ).

Table 3: Auxin content of three isogenic sunflower lines, ng/g fwt

\begin{tabular}{|c|c|c|c|c|c|c|c|c|}
\hline \multirow{3}{*}{$\begin{array}{l}\text { Geno- } \\
\text { type }\end{array}$} & \multirow{3}{*}{$\begin{array}{c}\text { Plant } \\
\text { number }\end{array}$} & \multirow{3}{*}{$\frac{\text { Phenotype }}{\text { Genotype }}$} & \multicolumn{6}{|c|}{ Ontogenetic phase } \\
\hline & & & \multicolumn{2}{|c|}{ Bud development } & \multicolumn{2}{|c|}{ Active growth } & \multicolumn{2}{|c|}{ Blossoming } \\
\hline & & & Apex & $\begin{array}{l}\text { Inflores- } \\
\text { cence }\end{array}$ & Apex & $\begin{array}{l}\text { Inflores- } \\
\text { cence }\end{array}$ & Apex & $\begin{array}{l}\text { Inflores- } \\
\text { cence }\end{array}$ \\
\hline MB 514 & & $\frac{\text { fertile }}{\text { F rfrf }}$ & $60.57 \pm 1.14$ & $75.80 \pm 1.23$ & $61.50 \pm 0.92$ & $76.90 \pm 2.26$ & $49.53 \pm 2.49$ & $85.40 \pm 0.28$ \\
\hline $\begin{array}{l}\text { MB514 } \\
\mathrm{cms}\end{array}$ & 58 & $\frac{\text { sterile }}{\text { S rfrf }}$ & $58.53 \pm 2.08$ & $73.20 \pm 2.22$ & 1.16 & $74.10 \pm 1.02$ & $48.00 \pm 2.08$ & $85.00 \pm 1.41$ \\
\hline $\begin{array}{l}\mathrm{MB} 514 \\
+\mathrm{GA}_{3}\end{array}$ & 10 & $\frac{\text { sterile }}{\text { F rfrf }}$ & $60.77 \pm 0.94$ & $75.57 \pm 0.77$ & $85.57 \pm 1.28$ & $88.47 \pm 3.21$ & $45.50 \pm 0.59$ & $83.80 \pm 0.71$ \\
\hline \multirow{2}{*}{ LSD } & & 0.95 & 0.120 & 0.064 & 0.526 & 0.241 & 0.138 & 0.037 \\
\hline & & 0.99 & 0.182 & 0.097 & 0.797 & 0.365 & 0.210 & 0.057 \\
\hline
\end{tabular}

$\mathrm{S}$ - male sterile cytoplasm containing mitochondrial orfH522; F - male fertile cytoplasm 
As a result of exogenous hormonal treatment, the microsporogenesis was blocked. This phenomenon is associated with significant increases of IAA amount during flower bud stage and active growth stages.

Also, it was found that the nucleic acids level, especially of RNA (Duca and Savca, 1998), and protein biosynthesis were increased (Duca et al., 1998). However, at the flower stage, the auxin content and the above mentioned parameters decreased below the corresponding values in the cms lines (Table 3). At this reproductive stage, the $\mathrm{cms}$ plants and those treated with gibberellins displayed abnormally developed anthers and lack of pollen.

Our results showed that maximal $\mathrm{GA}_{3}$ contents were in the apex and inflorescence tissues of the line MB 514 and also in plants exogenously treated with $\mathrm{GA}_{3}$. The lowest $\mathrm{GA}_{3}$ levels were was found in the cytoplasmic male sterile analogue - the line MB $514 \mathrm{cms}$ (Table 4).

Table 4: Gibberellin content in three sunflower isogenic lines, ng/g fwt

\begin{tabular}{|c|c|c|c|c|c|c|c|c|}
\hline \multirow{3}{*}{$\begin{array}{l}\text { Geno- } \\
\text { type }\end{array}$} & \multirow{3}{*}{$\begin{array}{c}\text { Plant } \\
\text { number }\end{array}$} & \multirow{3}{*}{$\frac{\text { Phenotype }}{\text { Genotype }}$} & \multicolumn{6}{|c|}{ Ontogenetic phase } \\
\hline & & & \multicolumn{2}{|c|}{ Bud development } & \multicolumn{2}{|c|}{ Active growth } & \multicolumn{2}{|c|}{ Blossoming } \\
\hline & & & Apex & $\begin{array}{l}\text { Inflores- } \\
\text { cence }\end{array}$ & Apex & $\begin{array}{l}\text { Inflores- } \\
\text { cence }\end{array}$ & Apex & $\begin{array}{l}\text { Inflores- } \\
\text { cence }\end{array}$ \\
\hline MB 514 & 60 & $\frac{\text { fertile }}{\text { F rfrf }}$ & $17.90 \pm 0.14$ & $18.50 \pm 0.33$ & $18.13 \pm 0.47$ & $16.26 \pm 0.32$ & $24.50 \pm 0.14$ & $18.37 \pm 1.18$ \\
\hline $\begin{array}{l}\text { MB514 } \\
\mathrm{cms}\end{array}$ & 58 & $\frac{\text { sterile }}{\text { S rfrf }}$ & $9.50 \pm 0.42$ & $7.20 \pm 0.57$ & $12.7 \pm 0.19$ & $6.70 \pm 0.47$ & $16.70 \pm 0.45$ & $1.33 \pm 0.43$ \\
\hline $\begin{array}{l}\mathrm{MB} 514 \\
+\mathrm{GA}_{3}\end{array}$ & 10 & $\frac{\text { sterile }}{\text { F rfff }}$ & $17.90 \pm 0.09$ & $18.50 \pm 0.33$ & $20.43 \pm 0.58$ & $16.80 \pm 0.19$ & $18.40 \pm 0.19$ & $13.40 \pm 0.52$ \\
\hline \multirow{2}{*}{ LSD } & & 0.95 & 0.786 & 1.082 & 0.570 & 1.051 & 0.506 & 0.573 \\
\hline & & 0.99 & 1.190 & 1.693 & 0.863 & 1.591 & 0.766 & 0.868 \\
\hline
\end{tabular}

$\mathrm{S}$ - male sterile cytoplasm containing mitochondrial orfH522; $\mathrm{F}$ - male fertile cytoplasm

During the flower stage, the gibberellin quantity in the $\mathrm{GA}_{3}$-treated line MB 514 decreased by approximately $30 \%$ in comparison with the $\mathrm{cms}$ analogue and by $20 \%$ compared with the untreated line MB 514. MB $514 \mathrm{cms}$ plants had low concentrations of this hormone unlike the male fertile plants in all studied ontogenetic phases. Gibberellin content increase in the fertile line MB 514 occurred during ontogenetic stages, reaching high levels at the flower stage (24.5 ng/g fwt). Exogenous gibberellin application changed its endogenous concentration. Maximal values of endogenous IAA and $\mathrm{GA}_{3}$ contents were determined at the flower bud stage, 24 hours post treatment and also during the active growth stage.

Data from the isogenic lines study provided more complete information related to auxin-gibberellin regulation of differentiation and generative processes in sunflower. Comparative analysis of endogenous auxin and gibberellin levels at different stages of microsporogenesis (Figures 2 and 3) revealed that the phytohormone con- 
centration in disk flowers decreased from the center of the inflorescence towards the periphery in all genotypes studied.

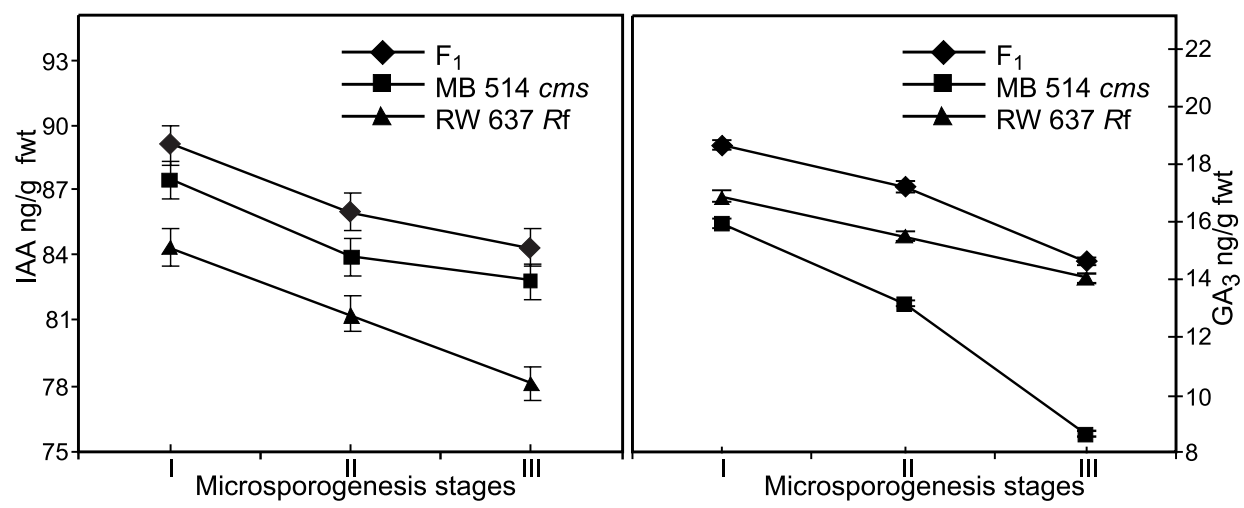

Figure 2: Phytohormone levels in flowers at various stages of microsporogenesis:

I - arhesporogenesis; II - sporogenesis; III - carpogenesis.
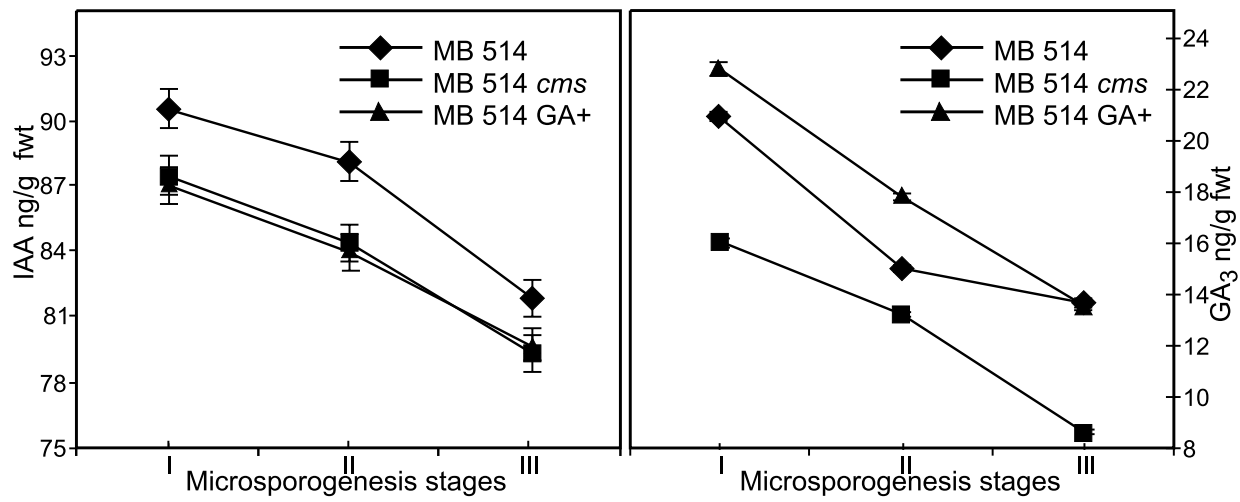

Figure 3: Different phytohormone levels in flowers of three isogenic sunflower lines during the following stages of microsporogenesis:

I- archesporogenesis; II - sporogenesis; III - carpogenesis

Our data support previous findings related to higher contents of both hormones in hybrid plants and the lowest IAA level in the male fertility restore lines, but the lowest $\mathrm{GA}_{3}$ level in the cms plants.

The exogenous GA treatment decreased the IAA concentration in disk flowers. The obtained results showed no significant difference between plants with induced male sterility and cms plants. However, the endogenous gibberellin content in the treated genotype was higher then those detected in the other two isogenic lines.

Beside the complex functional role of the studied parameters, the research on IAA and $\mathrm{GA}_{3}$ contents in different sunflower genotypes during ontogenesis revealed several features regarding growth regulators levels and genetics of the cms-Rf system. 
A high level of $\mathrm{GA}_{3}$ was present in the line RW $637 \mathrm{Rf}$ in comparison with the other genotypes, but the level kept decreasing in that line as well as in the $F_{1}$ hybrid. The line MB $514 \mathrm{cms}$ contained the lowest level of gibberellins that kept increasing during all the analyzed phases, even in disk flowers. The fertile line MB 514 (as well as the other male fertile genotypes) had higher auxin and gibberellin contents than its male sterile analogue during all studied phases.

Genotypic peculiarities related to auxin content were considerably lower in magnitude and less specific then those revealed for gibberellin content, apparently indicating a less significant functional role of the former in the phenotypic expression of the cms-Rf system. However, it could be supposed that high gibberellin content is associated with restored male fertility and low auxin content with pollen sterility.

Evidence of the requirements for GAs in male reproductive development of flowering plants has resulted from genetic and physiologic studies of GA biosynthesis mutants. Typically, in addition to the dwarf stature, the GA-deficient mutants exhibit various defects in reproductive development (Kende and Zeevaart, 1997; Fadeeva et al., 1980). Of the many plant growth regulators used as gametocides (Suster, 1962; Zdrilco and Poleacov, 1966; Frank et al., 1978) only gibberellins induce male sterility (Anascenko, 1971). This suggests that microsporogenesis development proceeds normally when the level of GA is normal. The low level of this hormone in the line MB $514 \mathrm{cms}$ and the high level in the line RW $637 \mathrm{Rf}$ (and in the other male fertile lines) seem to support the proposed hypothesis. Also, these conclusions are sustained by reports showing that tomato $s l_{2}$ gene mutants (nuclear male sterility) contain high IAA and abscisic acid contents but a low gibberellin content (Santokh and Sowhneu, 1993).

Thus it can be concluded that the quantitative differences in the auxin and gibberellin levels in various sunflower genotypes reveal that self-regulation of the cms$\mathrm{Rf}$ system in sunflower is mediated by endogenous phytohormones whose concentration depends on the genotype, ontogenetic phase and organ studied.

\section{CONCLUSIONS}

Quantification of endogenous IAA and $\mathrm{GA}_{3}$ levels during ontogenesis of five sunflower genotypes, completed by the study of two functional states of male gametophyte in the same nuclear context, revealed certain aspects of the interactions between genetic factors and phytohormones contributing to the male sterility-male fertility phenotype expression:

- the homozygous line MB $514 \mathrm{cms}$ had a lower level of endogenous GA that the fertility restorer line RW $637 \mathrm{Rf}$;

- highest amounts of IAA, regardless of tissues and ontogenetic phases analyzed, were found in the heterozygous $\mathrm{F}_{1}$ hybrid obtained by crossing the above lines;

- similar features of hormonal concentration were found in leaves, apices, inflorescences and disk flowers in most of the investigated variants. 
Genotypic peculiarities related to auxin content were considerably lower in magnitude and less specific then those revealed for gibberellin content, apparently indicating a less significant functional role of the former in the phenotypic expression of the cms-Rf system. It appears that high gibberellin content is associated with restored male fertility and low auxin content with pollen sterility.

\section{REFERENCES}

Anascenko, A.V., 1977. Dostizenia i perspectivi selektii podsolnecnika v mire. Moscow, pp. 153.

Anascenko, A.V., 1971. Osobennosti virascivania podsolnecnika pri khimicescoi castrati. Selectia i semenovodstvo 2: 36-38.

Anascenko, A.V., Duca, M.V., 1985a. Izucenie gheneticeskoi sistemi $\mathrm{cms}$-Rf u podsolnecnika (Helianthus annuus L.). Soobscenie 2. Vostonovlenie fertilnosti v cmsr. Ghenetica 12: 1999-2004.

Anascenko, A.V., Duca, M.V., 1985b. Изучение генетической системы cms-Rf у подсолнечника (Helianthus annuus L.). Сообщение 3. Востановливание фертильности в $\mathrm{cms}_{1}$. Генетика 12: 2005-2010.

Barlow, P.W., 1976. Towards an understanding of the behavior of root meristems. J. Theor. Biol. 57: 433-455.

Capatina, A., 2004. The cytogenetic study of different sunflower genotypes. Roumanian Biotechnological Letters. Bucharest 9: 1763-1770.

Cavell, B.D., Millan, J.M., Pryce, R.J., Sheppard, A.S., 1967. Plant hormones thin layer and gas-liquid chromatography of the gibberellins: Direct identification of the gibberellins in a crude plant extract by gas/liquid chromatography. Phytochem. 6: 867-874.

Collett, C.E., Harberd, N.G., Leyser, O., 2000. Hormonal interactions in the control of Arabidopsis hypocotyls elongation. Plant Physiol. 124: 553-561.

Duca, M., 1998. Aspecte genetice si fiziologice ale sistemului ASC-Rf la Helianthus annuus L. Autoreferatul tezei de doctor habilitat in stiinte biologice. Chisinau pp.1- 40.

Duca, M., Duca, Gh., Budeanu, O., 1997. Procedeu de determinare a fitohormonilor. BOPI. Brevetul (MD) Nr. 788.

Duca, M., Grigorcea, P., Birsan, A., Glijin, A., Libric, T., 1998. Influenta giberelinelor exogene asupra continutului de proteine hidroextractibile din frunzele si calatidiile de floareasoarelui. Conf. corpului didactico-stiintific "Bilantul activitatii stiintifice a USM pe anii 1996/97", pp. 199-201.

Duca, M., Port, A., Rotaru, T., 2003. Influence of diverse factors on the variability in auxin and gibberellin contents in Helianthus annuus L. Helia 26: 121-126.

Duca, M., Savca, E., 1998. Actiunea giberelinelor exogene asupra continutului de acizi nucleici la diferite genotipuri de floarea-soarelui Analele Stiintifice ale USM, Seria Stiinte ChimicoBiologice, Chisinau: 132-135.

Duca, M., Port, A.I., 2002. Dinamica unor indici fiziologici in ontogeneza diferitelor genotipuri de floarea-soarelui (Helianthus annuus L.). AN. I.C.C.P.T., LXIX: 232-243.

Fadeeva, T.S., Sosnihina, S.P., Ircaeva, N.M., 1980. Sravnitelinaea ghenetica rastenii: Leningrad, Leningradscogo universiteta: $234 \mathrm{p}$.

Frank, J.S., Koves, F.S., Szabo, M., 1978. Gibberellinel indukalt himsterilitas a napraforgonal. Novenytermeles 27: 487-492.

Horn, R., Kohler, R.H., Lossl, A., 1994. Development and molecular analysis of alloplasmatic male sterility in sunflower. Advances in Plant Breeding 18: 89-110.

Kasembe, J.N.R., 1967. Phenotypic restoration of fertility in a male sterile mutant by treatment with gibberellic acid. Nature 215: 668-670.

Kende, H., Zeevaart, J.A.D., 1997. The five “classical” plant hormones. Plant Cell. 9: 1197-1210.

Laver, H.K., Reynolds, S.J., 1991. Mitochondrial genome organization and expression associated with cytoplasmic male sterility in sunflower. Plant Journ. 1: 185-193.

Polevoi, V.V., Polevoi, A.V., 1992. Andoghennie fitogormoni etiolirovannih prorostcov cucuruzi. Fiziologia rastenii 39: 1165-1174.

Ross, J.J., O’Neil, P.D., 2001. New interactions between classical plant hormones. Trends Plant Sci. 6: 2-4. 
Santokh, S., Sowhneu, K.V., 1993. Hormonal regulation of stamen development and male sterility in tomato. Plant Physiol. 1: 65.

Savca, E., Duca, M., Popescu, I., Rotaru, T., 2002. Activitatea fotosintetica la diferite genotipuri de Helianthus annuus L. in ontogeneza. Analele Stiintifice ale Universitatii de Stat din Moldova, Chisinau 134-136.

Suster, V., 1962. Issledovania po iscustvennomu vizivaniu sterilinosti piliti u podsolinicinica. Seliscoie hozeastvo za rubejom 7: 22-24.

Symoons, G.M., Reid, J.B., 2002. Auxin-Gibberellin Interactions and Their Role in Plant Growth. J. Plant Growth Regul. 20: 346-353.

Voscoboinik, L.K., 1977. Selekcia na heterozise v Bolgarii. Biol. NTI po maslicnim culturam. Krasnodar, 1: 14-20.

Vranceanu, A., 1973. Masuri hotaratoare pentru obtinerea productiilor mari de floareasoarelui. Ann. ICCPT. Fundulea, 2: 13-18.

Vranceanu, A.V., Stoenescu, F.M., 1975. Ereditatea restaurarii fertilitatii polenului la floareasoarelui. Ann. ICCPT 43: 17-24.

Vranceanu, A.V., Stoenescu, F.M., 1971a. Manifestarea heterozisului la hibrizii simpli, triliniari si dubli de floarea-soarelui. Ann. ICCPT 34: 2-8.

Vranceanu, A.V., Stoenescu, F.M., 1971b. Pollen fertility restore gene from cultivated sunflower (H. annuus L.). Euphytica 20: 44-55.

Vronskih, M., 1980. Podsolnecinik v Moldavii. Kisinev, 178 p.

Zdrilco, A.F., Poleacov, I.M., 1966. Polucenie seliscohozeaistvennih pastenii s mujscoi sterilnosti vosdeistviem himiceschimi vescestvami: Selectia rastenii $\mathrm{s}$ ispolisovanii cytoplasmoticescoi sterilinosti. Kiev, 483-496.

\section{INTERACCIONES GENÉTICO-FITOHORMONALES EN LA EXPRESIÓN FENOTÍPICA DE LA ANDROFERTILIDAD Y ANDROESTERILIDAD EN GIRASOL (Helianthus annuus L.) Parte I: Investigación comparativa de la cantidad de auxinas y giberelinas en diversos genotipos de girasol \\ RESUMEN}

Se investigaron las cantidades de ácido 3-indol-acético (IAA) y ácido giberélico $\left(\mathrm{GA}_{3}\right)$ en tejidos vegetativos y reproductivos de diversos genotipos de girasol usando cromatografía líquido gaseosa. La cuantificación del contenido de $\mathrm{GA}_{3}$ endógeno de la línea homocigota MB514, caracterizada por androesterilidad citoplasmática $(\mathrm{cms})$, reveló un nivel menor que la línea restauradora de la fertilidad RW637Rf, que contiene una mayor cantidad de hormonas. El mayor contenido de IAA se encontró en el híbrido heterocigota $\mathrm{F}_{1}$ obtenido a partir del cruzamiento de estas líneas, independientemente de los tejidos y fases ontogénicas analizadas. Se encontraron resultados similares en hojas, ápices, inflorescencia y flores del disco en la mayoría de las variantes investigadas. 


\section{INTERACTIONS GÉNÉTIQUES PHYTOHORMONALES DANS L'EXPRESSION PHÉNOTYPIQUE D'UN MALE FERTILE ET MALE STERILE DU TOURNESOL (Helianthus annuus L.) Partie I: Recherche comparative de la quantité d'auxines et de gibberellins dans divers genotypes de tournesol \\ RÉSUMÉ}

Les quantités d'acide acétique 3-indole (IAA) et d'acide gibbelerellic ont été étudiées dans les tissus végétatifs et reproductifs de divers génotypes de tournesol, au moyen de la chromatographie en phase liquide. La quantification du contenu endogène $\mathrm{GA}_{3}$ de la lignée homozygote MB514, caractérisée par la stérilité male cytoplasmique $(\mathrm{cms})$, a révélé un niveau plus bas contrairement à la lignée restauratrice de fertilité RW637Rf qui contient une plus grande quantité d'hormones. La plus grande quantité de IAA a été trouvé dans l'hybride hétérozygote $\mathrm{F}_{1}$, obtenu par croisement de ces lignées, indépendamment des tissus et des phases d'ontogénèse analysés. Des résultats similaires ont été trouvés dans les feuilles, apex, inflorescences et disques foliaires dans la plupart des variantes examinées. 
